\title{
Konstrüktivizm ve Kimlik: Türkiye'nin Bosna-Hersek Savaşı Politikasının İncelenmesi
}

\author{
Merve BATTAL ${ }^{*}$
}

\section{ÖZET}

Bu çalışmada, konstrüktivist teori ve kimlik kavramı, Türkiye'nin Bosna-Hersek Savaşı politikası ile somutlaştırılarak incelenmiştir. $\mathrm{Bu}$ somutlaştırma işlemi konstrüktivizmin temel prensiplerine odaklanarak yapılmıştır. Bu prensipler; uluslararası siyaset teorisi için devletler analizin baş aktörleridir; devletler sisteminde en önemli yapılar maddiden ziyade intersubjektifdir; son olarak devlet kimlikleri ve çıkarları sosyal yapılar tarafindan inşa edilmiştir. Bu doğrultuda çalışmada öncelikle konstrüktivist teori açıklanmış ve bu teorinin temel argümanları tartıșılmıştır. Ardından kimlik konusu; kavramsal, teorideki yeri ve dış politika ile ilişkisi şeklinde incelenmiştir. Son olarak, Türkiye'nin Bosna-Hersek Savaşı politikası konstrüktivist teori ile analiz edilmiştir.
Araştırma Makalesi

Geliş: 24.08.2020

Kabul: 06.03.2021

Anahtar Kelimeler:

Konstrüktivizm, Kimlik, Türk Dış Politikası, Bosna-Hersek Savaşı

\section{Constructivism And Identity: Analysis of Turkish Foreign Policy Toward The Bosnian War}

\section{ABSTRACT}

In this study, constructivist theory and identity notion are analyzed to embody with Turkish foreign policy toward the Bosnian War. This embodying process is focused on basic principles of constructivism. These principles; states are the principles unit of analysis for intenational political theory; the key structures in the state system are intersubjective, rather than material; lastly state identities and interests are constructed by social structures. In this direction, firstly, constructivist theory is explained and basic arguments of this theory are discussed. Afterwards,identity issue is analyzed with conceptual, its place in theory and its relationship with foreign policy. Finally, Turkish foreign policy toward the Bosnian War is analyzed with constructivist theory.
Research Article

Received: 24.08.2020

Accepted: 06.03.2021

Keywords:

Constructivism, Identity, Turkish Foreign Policy, Bosnian War

* Süleyman Demirel Üniversitesi, Avrupa Birliği Çalışmaları Doktora Öğrencisi, mervebattal32@gmail.com, ORCID ID: https://orcid.org/0000-0003-2668-7608 


\section{GíRiş}

Genel olarak uluslararası ilişkiler teorileri pozitivist ve post-pozitivist olmak üzere ikiye ayrılabilir. Bilginin kaynağını görünür olanda arayan pozitivizm için objektif gerçekliğin dışında kalan her türlü yaklaşım bilim dışı kabul edilir. Pozitivizm, devletlerin uluslararası alanda tekrarlayan davranışlarını anlama ve böylece genelleme yapabilmesi adına katkı sağlamıştır. Uluslararası ilişkiler disiplininde, realizm, liberalizm, neo-realizm gibi yaklaşımlar pozitivizm içerisinde değerlendirilmektedir. Pozitivizmin, olayları maddi unsurlar üzerinden değerlendiği ve ahlak, kültür, kimlik, din gibi materyal unsurları dahil etmedikleri için açıklayamadığı olaylar olmuştur. Buna örnek olarak ise genelde Çanakkale Savaşında Batının yenilmesi ve Rusların Afganistan batağına saplanması verilmektedir. Özellikle Soğuk Savaşın bitmesinden sonra artan etnik çatışmalar, insan hakları ihlalleri, terörizm gibi olayları pozitivist teorilerin açıklayamaması üzerine post-pozitivist teoriler etkinliğini arttırmıştır. Genel olarak post-pozitivist teoriler içerisinde eleştirel teori, postmodernizm, feminizm, Marksist teoriler gibi yaklaşımlar bulunmaktadır. Konstrüktivist teori ise hem pozitivist hem de post pozitivist olarak değerlendirilmektedir. Bunun sebebi pozitivist epistomoloji ve post-pozitivist ontolojiyi bünyesinde barındırmasıdır. Konstrüktivizm bir yandan pozitivistlerin yaptığı gibi doğa ile toplumun birliğini kabul ederken, diğer yandan toplumun kendine özgü ontolojik bir karakteri olduğunu savunmaktadır (Karabulut, 2016:274-276).

Konstrüktivistler zaman içinde sosyal alanlarda yaşanan yapısal değişimleri çalışmalarına konu etmişler ve bu değişimleri sosyal, uzamsal ve tarihsel bağlam içerisinde değerlendirmişlerdir. Konstrüktivizm genel olarak yapı ve aktörün bu değişimlerden karşılıklı olarak etkilendiğini savunur. Öznelerarası etkileşim; kurallar, normlar, diller, anlamlar, kültür ve ideolojiler üzerinden şekillenmekte ve bu etkileşim sonucunda da kimlikler meydana gelmektedir. Bu sebeple konstrüktivist teorisyenlerin üzerinde en çok durduğu kavram kimliktir. Çıkar olgusunun asıl kaynağını kimlikler olarak gören konstrüktivizm, davranış ve kimlik üzerinden insani ilişkileri, oradan hareketle de uluslararası ilişkileri anlamlı kılmaya çalışmaktadır (Karabulut, 2016:194-195).

Yukarıda açıklanan konstrüktivist teori çalışmada; uluslararası ilişkiler teorileri arasında nasıl konumlandırıldığı ve tanımlandığı açıklandıktan sonra temel argümanlarından biri olan kimlik kavramı ile incelenecektir. Kimlik ise kavramsal olarak, konstrüktivist teori ile ilişkisi ve dış politikayla ilişkisi şeklinde ele alınacaktır. Son olarak ise konstrüktivist teoriyi ve kimlik kavramını somutlaştırmak adına Türkiye’nin Bosna-Hersek Savaşı politikası anlatılacaktır. Bu bölümde ise önce kısaca Bosna- Hersek'in tarihinden ve 1992-1995 yılları arasında yaşanan savaştan bahsedilecektir. Ardından Türkiye'nin bu savaşa yönelik politikası incelenecek ve konstrüktivist teori ile bu politika somutlaştırılacaktır. 
Genel olarak çalışmanın temel problematiğgi; konstrüktivist teori ve kimliğin, Türkiye'nin BosnaHersek Savaşı politikasını nasıl açıkladığı ve bu politikanın konstrüktivist teori ve kimlik çerçevesinde nasıl şekillendiğidir. Bu doğrultuda çalışmanın amacı, konstrüktivist teori ve kimlik kavramının, Türkiye'nin Bosna-Hersek Savaşı politikası ile somutlaştırılarak incelenmesidir. Çünkü devlet kimliklerinin ve çıkarlarının sosyal yapılar tarafından inşa edildiği argümanına dayanan konstrüktivizm, Türkiye’nin Bosna-Hersek savaşı politikası çok net açıklamaktadır. Türkiye’nin Cumhuriyetin ilanından bu yana Batılı dış politika kimliği doğrultusunda hareket etmesi ve Soğuk Savaştan sonra değişen uluslararası ortamda kendini kanıtlamak istemesi konstrüktivist teori ile açıklanabilmektedir. Ayrıca Türkiye'nin Bosna-Hersek ile ortak tarihi mirası ve geçmişinin bulunması; Türkiye'nin savaşta Boşnakların yanında yer almasını ve savaşın sonlandırılması için aktif dış politika yürütmesine neden olmuştur. Bu durum da uluslararası ortamda "Batılı" kimliği ile kendini kanıtlamak isteyen Türkiye için kolaylaştırıcı bir etken olmuştur.

\section{KONSTRÜKTIVIST TEORİ VE KIMLIKK}

Bu bölümde, 'Konstrüktivist Teori' ve 'Kimlik' kavramı incelenmiştir.

\section{Konstrüktivist Teori}

Konstrüktivist teorinin açıklanabilmesi için tarihsel gelişimine bakmakta fayda vardır. Bunun için de öncelikle uluslararası ilişkiler disiplinindeki üç büyük tartışmayı anlamak çok önemlidir. Bu üç tartışmadan birincisi, disiplinin terminolojisini ve ontolojisini belirleyen idealizm-realizm tartışmasıdır. Birinci Dünya Savaşının büyük tahribat yaratması, uluslararasında barış ve güvenliğin nasıl sağlanacağı sorusunun cevaplarının aranmasına neden olmuştur. İdealizm bu soruya insan hakları, demokrasi, uluslararası hukuk, uluslararası örgütlerin güçlendirilmesi gerektiğini söyleyerek cevap vermiştir (Ekici, 2018:9). Ancak realistlere göre bunlar uluslararası barış ve güvenliği sağlayamazlar. Bu yüzden her devlet kendi güvenliğini kendisi sağlamalıdır. Genel olarak uluslararası ilişkilerinin en temel kavramının güç olduğunu savunan realizme göre uluslararası sistem anarşiktir. $\mathrm{Bu}$ çatışmacı ortamda devletler hayatta kalabilmek için kendilerini koruyabilecek güce sahip olmalıdır (Karabulut, 2015:60).

Üç büyük tartışmadan ikincisi ise uluslararası ilişkiler disiplininin yöntemini belirleyen gelenekselcilik-davranışsalcılık tartışmasıdır. Bu tartışmada yeni şeyler söyleyen taraf davranışsalcılar olmuştur. Çünkü gelenekselcilik esas itibariyle idealizm ve realizm argümanlarının toplamıdır. Davranışsalcılar ise tartışmanın yeni tarafıdır ve disiplinin bir metodolojisinin olması gerektiğini savunan pozitivistlerden oluşmaktadır (Ekici, 2018:9). Davranışsalcıların temel savı, uluslararası ilişkilerin doğa bilimlerinde geçerli olan yöntemlerle araştırılması gerektiğidir (Tanrısever, 2019:106). Genel olarak gelenekselcilik- davranışsalcılık tartışması, kuramlar arasında bir tartışmadan ziyade tek 
bir kuramsal gelenek içinde araştırmacıların hangi teknikleri kullanacağına dair bir tartışma olarak değerlendirilebilir (Tanrısever, 2019:112).

Üçüncü büyük tartışma ise pozitivizm-post-pozitivizm tartışmasıdır. Sosyal bilimlerde 1980'li yıllardan itibaren en önemli tartışma eksenini oluşturan pozitivizm-post-pozitivizm kavgasının odak noktası epistemolojiktir. Genel olarak pozitivist epistemoloji, insanın rasyonelliği ön kabulünü taşır. Pozitivist yaklaşımlardaki ortak nokta, insanın özerk bir aktör olarak rasyonel olduğu varsayımıdır. Bu ön kabul, amprik yöntemlerin kullanılması yoluyla toplumsal olgularda genel geçer kanunların varlığının keşfini mümkün kılar. Ancak post-pozitivizm, rasyonelliğin sınırlarının tespit edilmesinin imkân dahilinde olmadığını savunur. Bu varsayımdan hareketle beşerî hayattaki ilişkilerin öznelerarası olduğunu, bu yüzden de toplumsal hayatta genel geçer kanunların belirlenme imkanının olmayacağını ileri sürer (Ateş, 2008:221).

Genel olarak üçüncü tartışmada tek bir doğrunun olamayacağı ve bu doğrunun da öznel unsurlar tarafından belirlendiği konuları yer almaktadır. Konstrüktivizm ise pozitivizm post-pozitivizm tartışmasında orta yol olarak görülmektedir. Bu şekilde tanımlanmasının sebebi iki tarafında görüşlerinin bazılarına yakın olmasıdır (Fierke, 2013:193). Nitekim Alexander Wendt (2016:60), çoğu kişinin birbiri ile bağdaşmadığını düşündüğü ontolojik ve epistomolojik durumları birbirleriyle uzlaştırarak "orta yol” (via media) inşa etmeyi amaçladığını belirtmiştir.

Felsefi olarak konstrüktivist düşüncenin kaynağı, bilginin sosyal bir inşa olduğunu öne süren idealist ve pragmatist felsefi yaklaşımlar olduğu söylenebilir. Kant ve Hegel gibi klasik düşünürler tarafından geliştirilen idealist felsefe, bilginin pasif bir öğrenim süreci değil, sosyal bir süreç olduğu ifade eder. Soğuk Savaşın bitmesiyle etkisini arttıran konstrüktivizmin kökenleri 18. Yüzyılda yapılan epistomolojik tartışmalarda aranabilir. Buna örnek olarak da İtalyan felsefecisi olan Giambatissa Vico'nun şu sözü verilir: "Doğal dünya Tanrı tarafından meydana getirilmiştir ancak tarihi dünya insanının ürünüdür.” Bu cümleden, insanların ve toplumların devletlerini doğal olarak da kendi tarihlerini inşa ettikleri anlamı çıkartılabilir (Emeklier, 2011: 160).

Genelde post-pozitivistler özelde ise konstrüktivistler sorgulanmadan kabul edilen gerçeklikle değil insanların ortaya çıkardığı gerçeklikle ilgilenir. İnsanlar dolayısıyla devletler, sistemi oluşturan faktörleri sistemle karşılıklı etkileşim sürecinde inşa etmektedir. Konstrüktivizm, bireylerin ve devletlerin dahil olduğu bu sosyal etkileşim sürecini inceleyerek bir anlamda uluslararası toplumun sosyolojisini yapmaktadır (Wendt, 1994:385).

Konstrüktivizm, insan bilincine ve onun dünya üzerindeki işlerine odaklanan bir yaklaşımdır. Pek çok uluslararası ilişkiler teorisi özellikle neorealizm, askeri güç, ekonomik kapasite, devletler arasındaki 
güç dengesi ve onların davranışlarını açıklamaya odaklanırken konstrüktivizm bu bakış açısını eleştirmiş ve uluslararası ilişkilerin maddi değil sosyal bir alan olduğu üzerinde durmuştur. Konstrüktivizme göre uluslararası ilişkileri de içeren sosyal ve politik dünya, insan bilincinin dışında olan fiziksel bir varlık ya da maddi bir nesne değildir (Jackson ve Sorensen, 2006:162). Bu sebeple konstrüktivizmde uluslararası kuralların, normların, kurumların, düşünsel unsurların ve bilişsel faktörlerin siyasi rolü üzerinde durulmuştur (Küçük, 2009:776). Realistler, liberaller ve Marksistler gibi baskın yapısalcı akımlar sadece yapıyı incelerken konstrüktivistler aktörleri de incelemelerine dahil etmiştir. Konstrüktivistler yapısal değişikliklerin ve devamlılıklarının aktörlere dayandığını söylemiş; benzer şekilde aktörlerinde içinde bulundukları sosyal, tarihsel ve mekânsal şartlar ile karş1lıklı etkileşim içinde olduklarını öne sürmüştür (Ertem, 2012:184).

Bu doğrultuda konstrüktivistlerin en önemli çıkış noktası, 1980li yıllarda özellikle neo-realist kuramın baskısı altında görmezden gelinen disiplinin toplumsal ve tarihsel boyutunu incelemesi olmuştur. Konstrüktivistler maddi unsurları da önemser ancak sosyal dünyanın oluşumunda düşünsel unsurların kurucu rol üstlendiğini ileri sürerler. Özellikle toplumsal bir özellik kazanmış olan düşüncelerin dünya politikasındaki rolüne vurgu yaparlar. Konstrüktivistler için aktörlerin kimlik ve çıkarları veri değil araştırma konusudur. Bu doğrultuda dünya politikasının öznelerarası boyutu (kurallar, normlar ve kurumlar), sosyal yapıları, aktörlerin kimlik ve çıkarları konstrüktivizmin başlıca odaklandığı konulardır. Konstrüktivizmi diğer yaklaşımlardan farklı kılan nokta düşünsel unsurlara birincil, özerk bir konum atfetmesi ve bu unsurların kurucu gücünü vurgulamasıdır (Küçük, 2009:777).

Konsrüktivizm, devlet, anarşi, kurallar-kurumlar ve yapı gibi konuları farklı bir bakış açısıyla incelemiştir. Konstrüktivizmde, diğer teorilerin çoğunda olduğu gibi analiz birimi devlettir. Çünkü sadece devlet meşru şiddet kullanma tekeline sahiptir. Y1kım araçlarına sahip olma devletin gücünün en üst noktasıdır ve bu durum devletin diğer aktörlerden ayırt edici olmasını sağlar. Wendt'e göre devlet, siyasal otoritenin yapısı olarak anlaşılır. Bu doğrultuda devlet, "aracılıklarıyla anlaşmazlıkların üstesinden gelindiği, toplumun yönetildiği ve sosyal ilişkilerin yönlendirildiği” normlar, kurallar ve ilkeler tarafindan oluşturulur. Bu yapı, gücün üç maddi temelini devlet ve toplumsal aktörlere paylaştırır. Bunlar; üretim araçları, yıkım araçları ve biyolojik yeniden üreme araçlarıdır. Farklı devlet yapısı şekilleri bu dağılımının organizasyonuna göre oluşur. Örneğin, kapitalist devlet sistemleri güç şekillerini sermaye, devlet ve aile arasında paylaştırırken; totaliter devlet yapıları onları devlet seçkinlerinde birleştirir. Fakat siyasal otoritenin belli bir düzende dağılımından bağımsız olarak devlet yapıları, daha önceden var olan öznelerin davranışlarını düzenleyen güç yapılarıdır. Bu güç yapıları ise öznelerin kim oldukları ve ne yapmaya yetkili olduklarını belirler (Wendt, 2016:254-256). 
Konstrüktivizmin farklı bir şekilde ele aldığ 1 anarşi ise kavram olarak oldukça tartışmalıdır. Wendt'e göre anarşi, en temel anlamda merkezi bir otoritenin yokluğudur. Uluslararası sistem, üst bir otoritenin olmaması nedeniyle anarşiktir. Bir başka deyişle anarşi, devletlerin üstünde başka bir yapılanmanın olmamasıdır. Tek başına bir anlam ifade etmeyen anarşiye sistem ve sistem içindeki ilişki anlam verir. Buradan hareketle tek başına 'anarşi mantığı' diye bir şeyin söz konusu olmadığı belirtilebilir (Wendt, 2016:378). Ayrıca Wendt, anarşinin geçici bir durum olarak algılanması gerektiğini söylemiştir. Wendt'e göre anarşi insanların düşüncelerinden yola çıkarak şekillenen, insanların dolayısıyla devletlerin eylemleri sonucunda oluşmuştur. Bir başka ifade ile Wendt için anarşi, devletler ondan ne anlıyorsa odur. Zira anarşi bir kendi kendine yetme sistemi olabilir ayrıca hiçbir neden olmaksızın kendi kendine yetmeye dayanmayan bir ortak güvenlik sistemi de olabilir. Hangi mantığın öncelikli olacağı ben ve öteki algılamalarına bağlıdır. Eğer devlet karşılaştığı aktörleri ilk anda tehdit olarak görürse bencil algılamalarını üreten rekabetçi dinamikleri harekete geçirecekken, dost olarak görürse farklı bir durum söz konusu olacaktır. Burada önemli olan devletlerin etkileşimleri ve bunun sonucunda oluşan çıkarların kimlikler üzerindeki etkisidir (Ertem, 2012:186).

Kurallar-kurumlar ve yapı arasında ilişki ise konstrüktivizmin incelediği en önemli temalardan biridir. Konstrüktivizme göre insan, çevresi ve doğa ile ilişki ve etkileşim halinde olan sosyal bir varlıktır. Bu süreç, sosyal bir yapı içerisinde ve birtakım kurallara bağlı olarak, amiller ve kurumlar aracılığıyla gerçekleşir. Konstrüktivizm, insanların toplumu, toplumun da insanları yaptığını varsayan bir yaklaşım ileri sürer. Bu durum, sürekliliği olan iki yönlü bir süreçtir. İnsanları ve toplumu birbirine bağlayan şey ise kurallardır. Hukuksal kuralların da bulunduğu bu sosyal kurallar, sürecin sürekli ve karşılıklı bir biçimde gerçekleşmesine neden olur. Bu bağlamda kuralların, bir insana neyi yapıp neyi yapmaması gerektiğini söyleyen genel ifadeler olduğu söylenebilir. Ayrıca kurallar, kurumların oluşumunda belirleyici bir etkiye sahiptir. Ek olarak kurallar, kurumlar ile amilleri birbirlerine bağlayan bir fonksiyon icra ederler. Bu yüzden sosyal yapının işleyişinde kurallar gibi kurumların da önemli bir rolü vardır. Kurumlar ise ilgili kural ve uygulamalardan oluşmaktadır. Amillerin amaçları doğrultusunda gerçekleşen faaliyetler ile kuralların oluşturduğu örüntüler, kurumları ortaya çıkarmaktadır. Burada amilliğin ne olduğuna değinmek önemlidir. Kısaca amillik müessesi statülerden, görevlerden ve rollerden oluşur. Amillerin kimler olacağını genellikle kurallar belirler. Amillik, ilgili toplum ölçeğinde ve kurallar aracılığıyla gerçekleşen bir şeydir. Kısacası insanlar ancak kuralların belirlediği şartlarda ve ait oldukları toplumun kapsamı ölçeğinde amil olabilmektedirler. Son olarak amiller, kurallar ve kurumlar bir sosyal yapı içerisinde var olurlar. Konstrüktivizm için yapı, aslında kurumların ve amillerin içinde faaliyet gösterdikleri bir şeydir. Konstrüktivizme göre yapının temelinde, dışarıdan da tanımlanabilen bir kurallar, kurumlar ve tercihler örüntüsünün varlığı 
bulunmaktadır (Kaya, 2008:96-98). Ek olarak kurallar, kurumlar, yapı hakkında Nicholas Onuf'un dört temel ön kabulüne değinmek faydalı olacaktır. Bunlardan ilki toplum ve bireyin sürekli bir biçimde birbirini oluşturmasıdır. Bu süreç toplumsal ilişkilerin sabit görünümü ve değişimini birlikte belirler. İkincisi ise dil ve onun türevleri olan kurallar ve kurumların toplumsal inşada araç olmasıdır. Çünkü insan isteklerini dille aktarır, isteklerini dille amaca dönüştürür ve bu amaçları doğrultusundaki hareketlerini dille destekler. Onuf'un üçüncü ön kabulü ise kuralların maddi varlıkları kaynağa dönüştürmesidir. Son ön kabul ise sosyal ilişkiler ağı içerisinde oluşturulan kurallar, kurumlar sonucunda bazı yapılanmalar inşa edilerek uluslararası ilişkilerin temel aktörleri olan devletlerin oluşturulmasıdır (Kaçar, 2014). Onuf’un ikinci ön kabulüne Bosna-Hersek Savaşı'ndan önce Sırpların kullandığg şiddet dili örnek verilebilir. Onuf’ un belirttiği gibi Sırplar katliamdan önce Büyük Sırbistan hayaline ulaşmak için Boşnakları, Müslümanları yok etmeleri gerektiğini meydanlarda, manifestolarda ifade etmiştir. Sonra da eyleme geçerek bunu gerçekleştirmeye çalışmışlardır. Sonrasında ise bu hareketleri uluslararası toplumda dille meşrulaştırmak istemişlerdir. Bunu da Avrupa'ya 'kendilerinin Avrupa'nın savunucusu olduğunu 'söyleyerek ve 'Müslümanlar Avrupa'yı ele geçirecek' gibi söylemlerle korku yaratarak yapmışlardır. Aslında kullandıkları bu yöntemle kısmen de olsa amaçlarına ulaşmayı başarabilmişlerdir.

Bunlara ek olarak konstrüktivist teori güvenlik kavramına da farklı bir bakış açısı getirmiştir. Sosyal ve düşünsel unsurların maddi yapılar üzerindeki belirleyiciliğini savunan konstrüktivist teori güvenlik kavramına bu açıdan yaklaşmıştır. Konstrüktivizm, güvenliği insanlar arasında karşılıklı etkileşim sonucunda kurulan bir olgu olarak tanımlamıştır. Ayrıca devlet odaklı güvenlik tanımlaması yerine güvenliğin sektörlere ayrılarak devletin güvenlik konusunda tek belirleyici olmadığını da vurgulamıştır (Buzan, Wæver ve De Wilde, 1998:7-8). Kısaca konstrüktivizm, güvenliği tüketilen bir olgu olarak değil üretilen bir olgu olarak kabul etmektedir (Karabulut, 2015:89-87).

Tüm bu anlatıların ışığında konstrüktivizmin, uluslararası ilişkilerdeki bir dizi ana temanın alternatif anlayışlarını sunduğu ifade edilebilir. Özellikle; anarşi, güç dengesi, çıkar ve kimlik arasındaki ilişki ve güç dağılımı konularında yeni yaklaşımlar getirerek diğer yaklaşımların açıklayamadığı sosyal faktörlerin gerek iç politikada gerekse dış politikada ki güçlü etkisini ortaya koyan bir yaklaşım olmuştur (Hopf, 1998:172).

\section{Kimlik}

Bu bölümde kimlik kavramı; 'Kavramsal Olarak Kimlik', 'Konstrüktivist Teori ve Kimlik Yaklaşımı' ve 'Kimlik ve Dış Politika' başlıkları altında incelenmiştir. 


\section{Kavramsal olarak kimlik}

Kimlik, günümüz dünyasında en büyüleyici ve ilgi çekici kavramlardan biridir. Bir özelliği, niteliği olan kimlikler her şeyden evvel farklılıkları ortaya çıkartır. Kimlik en geniş anlamda bireyin tüm özelliklerini kapsayan bir kavramdır. Kişinin kendisini nasıl gördüğü ve toplum tarafından nasıl görüldüğü, kimlik kavramıyla ilgili olan konulardır (Aşkın, 2007:213-214).

Disiplinler arası bir kavram olan kimliği psikologlar, benliği ve kişiliği kimliğin merkezine koyarak bu bağlamda tanımlamaya çalışırlar. Bu doğrultuda kimliği, bireyi diğer bireylerden farklılaştıran tutarlı ve yapılanmış göstergeler olarak tanımlamak mümkündür. Sosyologlar ise kimliği, toplumsal cinsiyet ve sinıf belirlemelerinde, bireyin sosyal durumunu ifade eden bir kavram olarak kullanırlar. Felsefede ise kimlik, öznenin varoluşunun ontik, epistemik ve estetik gibi belirlemeleri sonucunda ortaya çıkan gerçekliklerdir (Aşkın, 2007:214).

Kimlik kavramının tarihsel gelişiminde ilk göze çarpan husus bu kavramın Latince kökenli "idem” kelimesinden türediğidir. Kimlik (identity) kelimesi ilk kez John Locke ve David Hume tarafından “öz” (self) ile ilgili tartışmalarda kullanılmıştır. Sosyal bilimlerde ise kimlik kavramı 1950li yıllarda yoğun olarak kullanılmaya başlamıştır. Özellikle 1950li, 19601 yıllarda başta Erik Erikson olmak üzere, psikoloji alanında bireyin kimlik yapısı ve bunun toplumsal yansımaları üzere yapılan çalışmalar artmıştır.1970lerde ise Vietnam Savaşı, kimlik konusunun yalnızca psikoloji ve sosyoloji ile ilgili alanlarda değil siyasetle ilgili konularda da ele alınmasına sebep olmuştur (Ertem, 2012:191192).

Kimlik felsefi olarak bir şeyi o şey yapan unsurdur. Bir başka ifade ile kimlik, söz konusu varlığın kim ya da ne olduğunu belirlemektir. Bu doğrultuda kimlik varlığın kaçınılmaz bir boyutudur. Ancak kimliğin kaçınılmaz boyutunun olması onun verili olduğu anlamına gelmez. Nasıl tanımlanırsa tanımlansın inşa edilen bir kavram olan kimlik, sosyal bir fenomendir ve farklılık ilişkisi yoluyla oluşmaktadır. Kimliğin bilincine varılması, kimlerden farklı olunduğunun bilgisi ve yardımıyla mümkün olur (Ereker, 2010:56-57). Ek olarak kimlik, genellikle sosyal, kültürel ve jeopolitik çevreden etkilenir ve sabit bir şey değildir. Genel olarak kimlikler kendimizi nasıl gördüğümüz ve ne olmadığımızı düşündüğümüz algılar üzerine kuruludur. Bilimsel literatürde bu süreç diğerlerini tanımlama ve bu tanım üzerinden kendinin ne olduğunu belirlemedir (Lazaro, 2019:87).

Psikolojiden sosyolojiye, tarihten siyasete varan geniş bir alanın tartışma konusu olan kimlik kavramı için herkesin kabul edebileceği bir tanım yapmak zordur (Fearon, 1999:59). Yine de kimlik kavramı, "benlik duygusu" ya da "değerler bütünü" olarak basitçe tanımlanabilir. Ayrıca toplum ya da 
toplulukların "Kimsiniz" ya da "Kimlerdensiniz" sorularına verdikleri yanıt da kimliğin çoğunluğun hemfikir olabileceği bir tanımıdır (Akdemir, 2009:4-5).

Genelde biz kimiz sorusuna tarih, coğrafya, kültür, kolektif hafıza ve dinsel inançlar doğrultusunda bir cevap verilir. Bunun sebebi kimliğin birey ya da grup olarak kendimizi ve diğerlerini bulunduğumuz sosyal çevre içerisinde nereye, nasıl konumlandırdığımız ile ilgilidir. Kadın ya da erkek olmak, siyah ya da beyaz olmak gibi doğuştan gelen özellikler bazı temel parçaları belirlese de, kimlik aslında insanın kendi tercihlerinin bir sonucudur. Yani kimlik insanların eylemlerinden bağımsız değildir. Birey bir dönemde kimliğini oluşturan bir unsuru öne çıkarmayı tercih ederken başka bir dönem bunun tam tersini yapabilir. Bu durum eğitim, kültür yapısı, sosyal ve ekonomik şartlara bağlı olarak gerçekleşir. Amin Malaouf’a göre bu durumun nedeni kimliğin hangi unsurunun daha çok tehdit altında hissettiği ile ilgilidir. Şöyle ki ulusal kimliğinin tehdit altında olduğunu düşünen birinin ulusal aidiyetini, dinsel kimliğini tehdit altında düşünen birinin dinsel aidiyetini ön plana çıkarması beklenir. Yani kimliği oluşturan unsurlar arasında belirli bir hiyerarşi bulunsa da bu değişmez bir hiyerarşi değildir. Bu yüzden kimlik mevzu bahis olduğunda durağanlıktan değil dinamizmden bahsetmek daha doğrudur (Ertem, 2012:193).

Oldukça karmaşık bir yapıya sahip olan kimlik kavramından, sosyal bilimlerin farklı alanlarında farklı amaçlarla bahsedilmektedir. Özellikle sosyal psikolojinin önemli bir çalışma konusu olan kimlik kavramı farklı kategorilerde ele alınmaktadır. Örneğin toplumsal kimlik kategorisi, bireyin ait olduğu toplumsal çevrenin değerlerine, normlarına, akıl yürütmesine, sanatına, diline, dinine, gelenek ve göreneklerine ve diğer kurumlarına karşı geliştirdiği bir aidiyet bilincini ifade eder. Birey, kendi toplumu ve diğer toplumlar arasındaki benzerlikleri, zıtlıkları, çatışmaları, toplumsal kimliğe yüklediği anlam sınırları dahilinde tanır ve bu doğrultuda harekete geçer. Birey, toplumsal kimlik vasıtasıyla yaşam pratiklerine dahil olur. Toplumsal kimlik, çoğu zaman, bilinç ötesinde bir işlev yüklenerek bireyin bütün varlığına hükmeder (Özdemir, 2001:108). Bireysel kimlikle toplumsal kimliğin birbirinden ayrı düşünülemeyeceğini hemen belirtmek gerekir. Bireyin kendisine tekabül eden 'sen', 'o’ ya da 'onlar' duygusu olmazsa, ben duygusu diye bir şey ortaya çıkmaz (Şimşek, 2002:36). Bu doğrultuda bazı toplumsal kimlik kategorilerine etnik kimlikler, fiziksel kimlikler (çekik gözlü ya da beyaz tenli olmak gibi fiziksel özelliklerden kaynaklanan kimlik), sınıfsal kimlikler (işçi ve burjuva kimliği gibi), cinsel kimlikler (özellikle feminizm kimliği), dinsel kimlikler, siyasi kimlikler ve sosyal kimlikler örnek verilebilir. Bunların dışında Ankaralı olmak, taraftar olmak, Akdenizli ya da Doğu Anadolulu olmak, abla ya da kardeş olmak gibi bazı kimlik kategorileri de bulunmaktadır. Aslında bu alt kimlik kategorileri de çok önemlidir. Örneğin, taraftar olmak bir insan için etnik kimliğinden bile daha önemli bir kimlik olabilir (Karabulut, 2016:3-4). 
Bir bireyin, bir sosyal gruba (veya gruplara) üyeliği konusundaki bilgisinden türeyen bir kavram olan sosyal kimlik öz kavramının bir parçasıdır. Bu bakış açısına göre grup üyeliği insanlara sosyal dünyadaki yerleri hakkında bir fikir verir ve normlarını hayata geçirmek için rehberlik sağlar. Ayrıca kimlik gruplararası davranışın temelini oluşturur. Yani insanlar kendileri ve başkalarını grup üyeliği açısından gördükleri ölçüde tanımlarlar ve kişisel olarak ait oldukları sosyal grupla özdeşleşirler (Sindic ve Condor, 2014:39-54). Bu yüzden kimlik meselesinde karşılaştırmanın da önemli bir işlevi vardır. Karşılaştırma işlemi bireyin sosyal kimliğinin gelişiminde etkili bir faktördür. Kişinin kendini ve diğerlerini grup içi ve grup dışı olarak sınıflandırması kişinin ait olduğu grubun özelliklerini içselleştirmesine neden olur. Bu karşıllaştırma işleminin sonucunda birey, ait olduğu grubun öteki gruptan daha iyi olduğu sonucuna varır ve bu sayede aitlik duygusu güçlenir (Hogg ve Terry, 2000:121). Şöyle ki her kimlik ötekini içselleştirerek inşa edilir. Öteki tehdit oluşturuşa ya da tehdit olarak algılanırsa kimlik daha da güçlenir (Övet, 2007). Ek olarak kimliğin öteki kavramı ile bağlantılı olmasının en önemli nedeni, kimliğin toplumsal etkileşimin ürünü olarak ortaya çıkması ve bu yüzden de ait olma ihtiyacını içermesidir. Ötekini tanımlamadan veya kendi ile öteki arasındaki farkı ortaya koymadan öz-benliği tanımlamak mümkün değildir. Ötekinin oluşturulması ise söylem sayesinde olur. Söylemsel süreçte öz benlik kendi değerlerini diğer gruba empoze etmeye çalışır ve böylece ötekinin değerlerini düşürür. Öteki aşağılayıcı terimlerle ve damgalayacı klişelerle kolayca tanımlanabilir (Vukasovic, 2018:2-3). Bu durum Bosna-Hersek Savaşında yaşanan katliamların, işkencelerin bir nedenini açıklayabilir. Şöyle ki hem Sırplar hem de Hırvatlar geçmişten beri Boşnak kimliğini kabul etmemişlerdir. Hatta genel olarak Boşnakları "hain Sırp, hain Hırvat” şeklinde nitelendirerek onların kimliğini kabul etmediklerini göstermişlerdir.

\section{Konstrüktivist Teori ve Kimlik Yaklaşımı}

Gerçekliğin öznelerarası inşası, kurallar, dil, kimlik politikalarına vurgu yaparak pozitivist teorilerin açıklayamadığı olayları bu kavramlar üzerinden değerlendiren konstrüktivizme olan ilgi 199011 yıllardan itibaren artmaya başlamıştır. Kimlikleri amiller olarak tanımlayan konstrüktivizm, kimlik inşasının öneminin altını çizmiştir. Konstrüktivizm sosyal ilişkilerin temelinde sosyal aktörlerin kimliklerinin olduğunu ileri sürmektedir. Konstrüktivizme göre kimliklerin inşası ve dönüşümü sosyal aktörlerin temel çıkarlarını ve tercihlerini etkilemektedir (Karakoç, 2013:142-143).

Konstrüktivizm, kültür, normlar, inançlar gibi maddi olmayan faktörlere devlet kimliğini açıklamada öncelik verir. Konstrüktivizme göre kimlikler, devlet kimlikleri ve dolayısıyla çıkarlar süreç içerisinde değişebilir. Konstrüktivizm ayrıca devletlerin yalnızca kendi çıkarlarıyla hareket etmediklerini aynı zamanda bu çıkarları kimlikleriyle içselleştirerek davrandıklarını vurgulamaktadır (Alexandrov, 2003:33-34). Çıkar kavramını kimlikle sıkı bir şekilde bağdaştıran konstrüktivizme göre sabit bir 
"ulusal çıkar" yoktur. Wendt, aktörlerin ne yaptıklarıyla ne oldukları arasında sıkı bir ilişki olduğunu ifade etmiştir. Ne insan doğasından ne iç siyasi yapıdan ne de uluslararası sistemin kendisinden kaynaklanan bir uluslararası anarşi söz konusudur. Aslında tüm mesele uluslararası sistemde bilginin nasıl dağ̊ldığı ve devletler arasındaki etkileşimin nasıl şekillendiğidir. Bunda da devlet kimliği faktörünün rolü büyüktür (Wendt, 1992:398).

Konstrüktivist teoriye göre insanlar nesnelere karşı onların ifade ettiği anlamlar üzerinden hareket ederler. Devletler düşmanlarına ve dostlarına karşı farklı davranır çünkü düşmanlar tehdit eder, dostlar etmez. Anarşi ve güç dağılımı, kimin dost kimin düşman olduğunu anlama konusunda yeterli değildir. Çünkü İngiltere'nin füzeleri Amerika Birleşik Devletleri (ABD) için Rusya'nın füzelerinden farklı anlam taşır. Ya da ABD’nin askeri gücü Kanada ve Küba için farklı anlamlara gelir. Güç dağılımı devletlerin hesaplarını etkileyebilir ama bunun nasıl olduğu kendileri ve diğerleri hakkındaki düşüncelerini şekillendiren öznelerarası anlayışlara, beklentilere ve "bilgi dağılımına” bağlıdır. Wendt burada şu örneği vermektedir: Eğer ABD ve Sovyetler Birliği düşman olmadıklarına karar verirse Soğuk Savaş biter. Hareketlerimizi organize eden yapıları oluşturan şey kolektif anlamlardır. Yani kimlikler, belirli bir sosyallikte inşa edilmiş bir dünyada kimlik kazanırlar. Her insan kurumsal rolleriyle ilişkili olarak kardeş, öğretmen, vatandaş gibi birçok kimliğe sahiptir. Aynı şekilde devletlerde "bağımsız" “özgür dünyanın lideri” gibi pek çok kimliğe sahip olabilir. Belirli bir kimliğe olan bağlılık değişebilir ancak her kimlik aktörün kurumlar temelinde sosyal bir tanımlamasıdır ve aktörler bu kimliklerle kendilerini ve birbirlerini tanımlarlar (Wendt, 1992:397-398).

Konstrüktivizm ve kimlik konusunda Wendt'in dört kimlik tarifi oldukça önemlidir. Bunlardan ilki kurumsal/kişisel kimliktir. Bu kimlik türüne göre bir devleti devlet, kişiyi kişi yapan en önemli etken kimliktir. Bir aktör sadece bir tane bu tür bir kimliğe sahip olabilir. Bunun maddi temeli insanlar açısından beden, devletler açısından ise birçok beden ve topraktır. Ayrıca bu kimlik türü ortak hedefleri, düşünceleri, benlikleri, kişiliği olan kolektif bir kimliğe sahip bireyler tarafindan yönlendirilmektedir. Bu kimlikte, benlik bilinçlidir ve bellek önemli bir yere sahiptir. İkincisi, sosyal bir kategoriye, statüye, sınıflandırmaya ait tip kimliğidir. Yani tutumlar, değerler, yetenekler, bilgi, görüşler, deneyim, bölge ya da doğum yeri, dil, tarihi ortak özellikler ya da özellikleri görünüşte paylaşan ya da paylaştığı varsayılan insanlar için kullanılan etiketler bu türün içerisine girmektedir. Ancak rol ve kolektif kimlik türlerinden farklı olarak bu temeli oluşturan nitelikler aktöre içkindir. Öteki var olsa da olmasa da mevcuttur. Üçüncüsü ise rol kimliktir. Rol kimliğin gelişebilmesi için bir öteki şarttır. Zira doğuştan var olan niteliklere dayanmaz ve böylece sadece ötekilerle ilişkili olarak var olabilir. Sonuncusu olan kolektif kimlik ise, biz duygusunun ön plana çıktığı, ortak değerlerin, 
hedeflerin, amaçların olduğu, aynı duygu ve düşüncenin paylaşıldığı çıkar birliğine dayalı kimliktir (Wendt, 2016:280-284).

\section{Kimlik ve Dış Politika}

Konstrüktivizm için devletler sosyal aktörlerdir. Bu sebeple devletler kurallar ve uygunluk arayış1 içerisinde kimlik oluşturmaya ve onu ifade etmeye ihtiyaç duyan yapılardır. Ulusal çıkar ve ulusal kimlik konularını farklı bakış açısıyla değerlendiren konstrüktivizmde; ulusal çıkarlar sabit olmayan ve ulusal kimlikten fazlasıyla etkilenen değişken verileridir. Kendisi de sabit olmayan ulusal kimlik uluslararası ve ülke içi güçler tarafından şekillenir ve değişir. Şekillenen ve değişen ulusal kimlik de ulusal çıkarları etkiler ve zamanla bu çıkarları da değiştirir. Bu yüzden devletlerin uluslararası sistemde nasıl davrandığını ve dış politika kararlarını anlayabilmek için bu kavramlara odaklanmak gerekir. Konstrüktivistlere göre devletlerin iletişimleri ve etkileşimleri kimliklerin ve çıkarların şekillenmesinde önemli rol oynar (Öztürk, 2014:2-3).

Bir devleti belirli bir kimliğe göre değerlendirmek eylemler açısından farklı sonuçlar meydana getirir. Örnek vermek gerekirse, güçlü-zayıf devlet kimlikleri, Avrupa Birliği üyesi ya da NATO üyesi devlet veya saldırgan-barışcıl devlet kimlikleri farklı davranışsal sonuçlara neden olur çünkü her bir kimliğin meydana getirildiği çıkarlar birbirinden farklıdır. Bu sebeple bir devletin dış politika eylemlerini açıklamak için çıkarları, bunun için de öncelikle kimliği anlamak önemlidir (Ereker, 2010:61).

Devletler, uluslararası sistemde bilinmek istediği kimlikler doğrultusunda politikalar yapar ve benzer şekilde etkileşime geçtiği devletin onaylanmış kimliği doğrultusunda hareket eder. Bu durumda ötekini düşman olarak konumlandırmak dış politika açısından çok önemlidir. Wendt, ötekini düşman olarak konumlandırmanın tarih boyunca var olduğunu ifade etmiştir. Buna da örnek olarak Antik Yunanlıların Persleri 'barbarlar' olarak göstermelerini vermiştir. Ayrıca ötekinin düşman olarak konumlandırma işleminin yakın zamanda da görülebileceğini vurgulayan Wendt, bunu Bosna- Hersek Savaş1, Ruanda İç Savaşıyla destekleyerek örneklendirmiştir (Wendt, 2016:322-323).

Wendt'e göre kimlik ve çıkarlar etkileşim sürecinde inşa edilmektedir. Bu etkileşim öncesinde aktörlerin benlikleri yoktur ve yalnızca örgütsel yönetim mekanizması ile bunu koruma arzusundadırlar. Wendt, etkileşim öncesi kimliklerden kaynaklanan dört bağımsız çıkar olduğunu ifade eder. Bu çıkarlar realizmde olduğu gibi verili, sabit ve tüm aktörler için aynıdır. Bunlar; fiziksel güvenliği korumak, otonomiyi korumak, ekonomik refahı ve kolektif kendine saygıyı korumaktır (Ereker, 2010:61).

Kimlik yaratma pratikleri, devletlerin uluslaşma süreçleriyle ilgilidir. Bu süreçte kolektif hafızanın önemli bir rolü vardır. Bunun sebebi ise kolektif hafızanın sembol, mit, inanç, alışkanlık ve inançlar 
yoluyla inşa edilmesidir. Kimlik oluşturulduktan sonra devletler bir taraftan bu kimliklerini iç siyasette ve uluslararası alanda kurumsallaştırmaya çalışırken, diğer taraftan iç siyaset ve uluslararası alanın oluşturduğu etkiler kimlikleri şekillendirmeye başlar. İç siyasette kimliğin sürekli canlı tutulmaya çalışılması devletlerin meşrutiyetlerini devam ettirmeleri için önemlidir. Bunu canlı tutmanın en iyi yolu ise dış politikadır. Bu doğrultuda dış tehdit, tehlike unsurlarının dış politikanın kimliğini koruyucu rolü bulunduğu söylenebilir. Bunun nedeni ise devletlerin, kimliğin dişardan ve içeriden gelecek tehditlere karşı koruma sorumluluğun olmasıdır. Bu doğrultuda dış politika ve kimlik arasındaki ilişkinin karşılıklı inşa edici olduğu söylenebilir (Ereker, 2010:63).

Özetle, Konstrüktivist teori açısından bakıldığında, devlet kimliği bağımsız değişken, dış politika ise bağımlı değişken olarak ele alındığında devletlerin kendilerini diğer aktörlere karşı nasıl tanımladıklarının, çıkarların belirlenmesinde büyük rolü olduğu söylenebilir. Kimlikle ilişkili olarak belirlenen çıkarlar da uygulanacak dış politika davranışı üzerinde etkili rol oynamaktadır (Çoşkun, 2007:64).

\section{KONSTRÜKTIVIST TEORİ İLE TÜRKIYE'NIN BOSNA-HERSEK SAVAŞI POLITIIKASININ INCELENMESI}

Bu bölümde öncelikle 'Bosna-Hersek Savaşı' anlatılmıştır. Ardından 'Türkiye'nin Bosna-Hersek Savaşı Politikası' açıklanmış ve daha sonra 'Konstrüktivist Teori ile Türkiye’nin Bosna-Hersek Savaşı Politikası' incelenmiştir.

\section{Bosna-Hersek Savaşı}

Bosna, tarihte ilk defa Orta Çağda bağımsız devlet olarak ortaya çıkmış ve 1326'da Hersek ile birleşmiştir. Osmanlının fethetmesine kadar olan süreçte ise Hırvat ve Macar yönetimi altında kalmıştır. Bu dönemde Katolikliği ve Ortodoksluğu reddeden ayrı Bogomil inancına dayanan Bosna kilisesi oluşturulmuştur.1463'de Osmanlı tarafından fethedilen Bosna'nın Müslümanlığı kabul etmesinde Bogomil inancının etkili olduğu düşünülebilir. Bosna-Hersek yaklaşık dört yüzyıl boyunca önce sancak, ardından eyalet olarak siyasi kimliğini korumuştur. Dört yüzyıl Osmanlı egemenliğinde kalan Bosna-Hersek 1878 Ayastefenos Antlaşması ile otonomi kazanmış, altı ay sonra imzalanan Berlin Antlaşması ile Avusturya-Macaristan yönetimine verilmiştir.1908 yılında ise AvusturyaMacaristan imparatorluğu tarafından ilhak edilmiştir (Kenar, 2005:15-16). Avusturya döneminde Bosna ayrı bir idari birim olarak tutulmuştur. Birinci Dünya Savaşı'nda ise Boşnaklar İtilaf devletlerine karşı savaşmış, savaş onların lehine sonuçlanınca Avusturya-Macaristan İmparatorluğu parçalanmıştır. Ardından bölgede yaşayan halklar (Hırvatlar, Slovenler, Boşnaklar ve Sırplar) Sırbistan ve Karadağ ile birleşerek Yugoslavya’yı kurmuşlardır. Bu dönemde Bosna, diğer halklar gibi 
siyasi kimliğini kaybetmiştir (Karatay, 2002:4). Yugoslavya, 1941 yılında Mihver devletleri tarafından işgal edilmiştir. Bosna-Hersek, işgal süresince Almanya'nın kurup Hırvatlara hediye ettiği 'Bağımsız Hırvat Devleti' sınırları içinde kalmıştır. Sosyalistlerin başlattığı kurtuluş harekâtı neticesinde, Sosyalist Federal Yugoslavya Cumhuriyeti kurulmuştur. Yeni kurulan bu devletin siyasal sistemi, Ocak 1946'da ilan edilen ve resmi olarak beş Yugoslav milletini tanıyan Anayasa ile oluşmuştur. Anayasanın tanımış olduğu milletler içinde Bosnalı Müslümanlar olmamasına rağmen, Bosna-Hersek Yugoslavya'yı oluşturan altı kurucu cumhuriyetten biri olarak ilan edilmiştir (Öner, 2013:31). Farklı milletleri izlediği politikalarla bir arada tutmayı başaran Josip Broz Tito'nun ölümünün ardından Yugoslavya çatırdamaya başlamıştır. Soğuk Savaşın sona ermesi ve komünizmin çökmesi Yugoslavya’yı doğrudan etkilemiş, 1991 yılında Hırvatistan ve Slovenya'nın bağımsızlıklarını ilan etmeleriyle Yugoslavya fiilen parçalanmaya başlamıştır. Artan Sırp milliyetçiliği içinde kendini güvende hissetmeyen Bosna-Hersek 3 Mart 1992'de bağımsızlığını ilan etmiştir. 6 Nisan Avrupa Topluluğu ve 7 Nisan 1992'de de ABD tarafından bağımsız bir devlet olarak tanınmıştır (Bağc1, 1994:258). Bağımsızlığın ilanı ile birlikte, bağımsızlığı boykot eden Sırplar saldırıya geçmiş ve üç yıldan fazla sürecek olan Bosna-Hersek Savaşı başlamıştır. İkinci Dünya Savaşından sonra Avrupa, yeniden toplama kampları, soykırım, işkence ve sistematik tecavüz gibi insanlık onurunu zedeleyen durumlarla karşılaşmıştır. Çok ağır bir travmaya maruz kalan ve çoğunlukla Boşnak olan bu insanlar halen yaşadıklarını unutamamıştır. Uluslararası toplum örgütler ve devletler nezdinde çeşitli planlar, kararlar ve yaptırımlarla savaşı durdurmak için girişimlerde bulunmuştur. Ancak bu girişimler Büyük Sırbistan hayaline kapılmış Sırp liderleri durduramamış, soykırıma engel olamamıştır. Ayrıca bu yaşananlar medya sayesinde her ne kadar engellenmeye çalışılsa da insanlara ulaşmış ve büyük tepkiyle karşılanmıştır. Artan uluslararası kamuoyunun tepkisi neticesinde NATO geç gelen bir müdahalede bulunmuştur. Bu müdahale ile savaşı sona erdirecek zemin oluşmuştur. Ardından mekik diplomasisi başlamış, uluslararası toplumun çabalarıyla taraflar bir araya getirilmiştir. Akabinde 14 Aralık 1995'de Dayton Antlaşması imzalanmıştır. Dayton Antlaşması ile kısa zamanda çatışmanın durdurulması, uzun zamanda ise kalıcı barış ve istikrarlı bir devlet hedeflenmiştir. Ancak Dayton Antlaşması'nın eleştirilen pek çok noktası vardır. En önemlisi ise Bosna-Hersek'in sınırlarının, etnik grupların savaşın sonunda elinde tuttukları topraklara, çoğunlukta oldukları bölgelere göre belirlenmiş olmasıdır. Dayton Antlaşması'yla Bosna-Hersek’in siyasi ve idari mekanizması oldukça karmaşık bir şekilde oluşturulmuştur. Bu karmaşıklık günümüzde Bosna-Hersek'in siyasi, ekonomik ve hukuki gelişmesinin önünde engel oluşturmaktadır.

Savaş, Bosna’ya unutulması zor kötülükler yaşatmıştır. Bosnalılar bu savaşta katliam, soykırım, sistematik tecavüz, toplama kampları, toplu mezarlar ve işkence gibi kelimelerin anlamlarını yaşayarak 
acı bir şekilde öğrenmişlerdir. Saraybosna 5 Nisan 1992- 29 Şubat 1996 tarihleri arasında kuşatma altında kalmış ve modern savaş tarihinin en uzun kuşatması olarak tarihe geçmiştir. Her gün ortalama 329 bombanın vurduğu Saraybosna'da 10 bin insan ölmüş, 56 bin insan yaralanmıştır. Saraybosna'da sadece bir günde, 22 Temmuz 1993 tarihinde 3777 bomba patlamıştır. Yaklaşık 100 bin bina kuşatma sırasında zarar görmüştür (Sabah Gazetesi, 2010). Eski Yugoslavya Uluslararası Ceza Mahkemesi araştırmalarına göre sadece Saraybosna'da kuşatma altında kaldığg sürede toplam 18.889 kişi hayatını kaybetmiştir (Cekic, 2018:47-48). Yalnızca 1992 yılının Temmuz-Ağustos aylarında, Saraybosna'da 750.000 kişi evsiz kalmış, 30.000 insan açlıkla mücadele etmiş ve binlerce insan tıbbi yetersizlikten yaşamını yitirmiştir (Sonyel, 1994:32).

Avrupa kıtası, İkinci Dünya Savaşında Nazilerin kurduğu toplama kamplarından sonra bir kez daha toplama kamplarına tanık olmuştur. Sırplar, Bosna-Hersek’te toplama kampları oluşturmuş ve bu kamplarda binlerce insan hayatını kaybetmiş, işkenceye uğramıştır. İnsanlık trajedisinin yaşandığı toplama kamplarında 200 bin civarında insan işkencelere maruz kalmıştır. Öyle ki Bosna' daki toplama kamplarında, daha önce bilinmeyen 80 yeni işkence türü uygulanmıştır (Türbedar, 2008:9). Saldırganlar, Müslümanların vücutlarına makas ve bıçak kullanarak haç işaretini çizmek, kor demirlerle damgalamak, mağdurları çivileyerek tahta çarmıha germek gibi işkenceler yapmıştır (Cekic, 2018:73). Genel olarak bu savaşın acı bilançosu ise şu şekildedir: Savaşta 200 binden fazla sivil hayatını kaybetti, 2 milyondan fazla kişi göç etti ve mal varlıklarına el konuldu, 44 bin Boşnak kadın sistematik tecavüze maruz kaldı. Şimdiye kadar ise 500'den fazla toplu mezar, 5000'nin üzerinde müstakil mezar bulundu. Resmi kayıtlarda 31.500 kişi kayıp olarak geçti ve bugüne kadar 22.000 kaybın cenazesine ulaşıldı (Cekic, 2018:10-11).

\section{Türkiye'nin Bosna-Hersek Savaşı Politikası}

Türkiye'nin bu kanlı savaşa yönelik politikasında ilk değinilmesi gereken nokta siyasi, kültürel ve coğrafi açıdan bir Balkan ülkesi olmasıdır. Türkiye'nin Trakya bölgesi Balkan coğrafyası sınırları içerisinde bulunmaktadır. Buna ek olarak Osmanlı Devleti'nin dört yüz yılı aşkın bir süre Balkan bölgesinin hakimiyetini elinde bulundurmuş olması, Türkiye ile Bosna-Hersek arasında ortak tarihi mirası oluşturmuştur. Diğer taraftan Balkanlarda yaşanan gelişmeler Türkiye’yi doğrudan olarak etkilemektedir. Çünkü bu bölgede herhangi bir kriz çıktığında en çok göçü Türkiye almaktadır. Ayrıca coğrafi olarak Balkanlar, Türkiye için stratejik bir geçiş koridoru olduğundan hayati önem taşımaktadır (Özlem, 2010:28).

1992 yılında Bosna-Hersek savaşının patlak vermesinden itibaren Türkiye sorunun çözümü için aktif uluslararası diplomasi yürütmüştür. Yugoslavya’nın parçalanma sinyalleri verildiğinde Türkiye geleneksel Türk dış politikası çerçevesinde, Yugoslavya'nın bütünlüğünün korunmasından yana 
olmuştur. Ancak Yugoslavya'nın dağılmaya başlamasıyla Türkiye politikasında değişiklik yapmış ve tarihi bağı olduğu Bosna-Hersek'in tarafında olduğunu belirtmiştir. Türkiye, daha savaşın başında uluslararası askeri müdahaleden yana olduğunu bildirmiştir. Bu doğrultuda, Uluslararası Barış Gücüne Türkiye'nin katılmasının ilk adımı olarak, 8 Aralık 1992 tarihinde TBMM, Bosna-Hersek'e asker göndermeye izin veren kanunu onaylamıştır. Özellikle dönemin Cumhurbaşkanı Turgut Özal, Bosna’ya asker gönderilmesi en başından beri desteklemiştir. Dönemin Dışişleri Müsteşarı Onur Öymen, savaşın başında NATO’ya müracaat edip, sınırlı hava harekâtı yapılmasını talep ettiklerini ancak bu isteğinin kabul edilmediğini söylemiştir. $\mathrm{Bu}$ isteğin değerlendirilmemesinde, Batılı devletlerin ortak tarihi geçmişten dolayı Türkiye'nin savaşta tarafsız olamayacağı düşüncesinin etkisi vardır (Emgili, 2012:71-80).

Asker gönderme girişiminin başarısız olmasının ardından Türkiye, Bosna-Hersek'in uluslararası alanda tanınması için çabalamıştır. Türkiye, Sırpların şiddete yönelik eylemlerini kınarken, BosnaHersek'in Birleşmiş Milletlere (BM) üye olmasının faydalı olacağı düşüncesiyle hareket etmiştir. Türkiye'nin çabaları neticesinde Bosna-Hersek 22 Mayıs 1992'de BM'ye üye olmuştur. Ancak bu hareket Sırpların saldırını durduramamıştır (Sağır, 2016).

Türkiye, savaş esnasında uluslararası toplumu duruma müdahil olması için ikna etmeye çalışmıştır. Bunun için de iki farklı girişimde bulunmuştur. Bunlardan ilki Batı dünyasıdır. Bu doğrultuda Türkiye $\mathrm{ABD}, \mathrm{BM}$ ve Avrupa Birliği çerçevesinde sayısız diplomatik girişimde bulunmuştur. ABD ve Türkiye'nin Bosna-Hersek politikasında paralellik bulunmasından dolayı ABD, Türkiye'nin BosnaHersek politikasını desteklemiştir (Sağır, 2016). Türkiye’nin ikinci girişimi ise İslam ülkelerinin dikkatini çekmeye çalışmasıdır. İslami ülkelerle ilgili, Türkiye Bosna Savaşında aynı tavrı benimseyen tüm ülkeleri bir araya getirmeyi deneyerek İslam İşbirliği Teşkilatı platformunu kullanmıştır. Haziran 1992'de İstanbul'da olağanüstü yapılan İslam İşbirliği Teşkilatı zirvesi, konu üzerinde ortak bir noktanın kabul edilebilirliğine yol açan önemli bir girişim olmuştur (Çoşkun, 2011:14).

Türkiye çatışmaların durdurulması amacıyla, BM ve NATO tarafından oluşturulan güçlere katılmıştır. Türk Hava ve Deniz Kuvvetleri Bosna'da çeşitli görevler üstlenmiştir. BM’nin 30 Mart 1993'de aldığ 1 "Bosna-Hersek hava sahasına uçuş yasağı” kararının uygulanmasını denetlemek için operasyon yapılmış ve Türkiye bu operasyona 18 adet F-16 uçağı ile katılmıştır. Ayrıca Türkiye bu dönemde, Surbistan'a uygulanan ambargonun denetimi için Adriyatik Denizinde bulundurulan hava ve deniz kuvvetlerine destek vermiştir. Türkiye tek taraflı müdahaleden kaçınarak uluslararası toplumla beraber hareket etmiştir. 1994 yılına gelindiğinde, uluslararası toplum tarafından çatışmayı durdurmak için yapılan planlara, alınan kararlara rağmen çatışmalar dinmemiştir. Dönemin başbakanı Tansu Çiller ve Pakistan başbakanı Benazir Butto, yaşanan savaşı dünya kamuoyuna duyurmak için Bosna-Hersek’e 
gitmiştir. Çiller ile Butto, Saraybosna'da ortak bildiri yayımlamış, Bosna-Hersek'e uygulanan silah ambargosunun kaldırılmasını ve burada akan kanın durdurulmasını istemişlerdir. Yine bu dönemde ABD ve Türkiye, taraflar arasındaki güç dengesizliğini savaşın sebebi olarak değerlendirdiğinden, Boşnak-Hırvat Federasyonunun askerî açıdan güçlendirilmesini istemiştir. Bu çerçevede Türkiye, 150200 Bosnalı askere eğitim vermiştir. Akabinde, 1500 kişilik Türk Birliği 1994 Temmuz ayında Zenica'ya yerleşmiş ve Hırvatlar ile Boşnaklar arasındaki ateşkesi gözlemlemiştir. Boşnaklar ile Hırvatlar arasında ateşkesin sağlanmasında Türkiye'nin önemli katkısı olmuştur. Dönemin Cumhurbaşkanı Süleyman Demirel, ateşkesin gerçekleşmesi için Franjo Tudjman ile dostane ilişkiler kurmuştur. Bu ilişkiler Bosna-Hersek’te barışın sağlanmasına zemin hazırlamıştır. Türkiye tüm bu girişimleri Balkanlarda istikrar ve güven ortamının sağlanması için yapmıştır (Sağır, 2016).

\section{Konstrüktivist Teori ile Türkiye’nin Bosna-Hersek Savaşı Politikası}

Konstrüktivist teori ile Türkiye'nin Bosna-Hersek Savaşı politikasını değerlendirmeden önce Soğuk Savaş sonrası Türkiye'nin Balkanlar politikasına değinmek yerinde olacaktır. Bilindiği gibi Soğuk Savaş döneminde Türkiye'nin Balkanlar politikası sınırlı ölçekte kalmıştır. Özellikle İkinci Dünya Savaşından sonra Balkanlarda sosyalist rejimlerinin kurulması bu dönemde Türkiye'nin Balkanlardan uzak kalmasına yol açan en önemli nedenlerden biri olmuştur. 1953 Balkan Paktı ve 1954 Balkan İttifakı hariç Türkiye'nin Balkan devletleri ile ilişkisi sınırlı düzeyde seyretmiştir. Genel itibariyle bu dönemde Türkiye'nin Balkanlarla ilgili politikasının odak noktasını Yunanistan ile yaşanan Kıbrıs, Ege Denizi, azınlık sorunu gibi gerilimler oluşturmuştur (Sancaktar, 2010).

Soğuk Savaş yıllarında Türkiye, dış politikasını büyük güçlerin tutumlarına göre oluştururken,1990ların başından itibaren değişen konjonktürün de etkisiyle Türkiye, Kafkasya, Orta Doğu ve Balkanlar politikasında yeni girişimler başlatmıştır (Çoşkun, 2013:164). Bunun en önemli sebebi ise dünyanın en çalkantılı bölgeleri olan Kafkasya, Balkanlar ve Orta Doğu'nun Türkiye’nin sınırları olmasıdır. Bu bölgelerin hızlı bir değişkenlik yaşaması, Türkiye’nin Soğuk Savaş öncesine oranla bu bölgelerde daha aktif olmasına yol açmıştır (Oran, 1995:278).

Soğuk Savaştan sonra Türkiye'nin Balkanlar politikasının aktifleşmesinde üç çıkar önemli bir yere sahiptir. Bunlardan ilki Türkiye'nin coğrafi, tarihsel ve kültürel olarak bir Balkan ülkesi olmasıdır. İkincisi Balkanların Türkiye ile Batı Avrupa arasında stratejik bir konumda bulunmasıdır. Üçüncüsü ise Türkiye'nin Balkanlardaki bazı halkalarla (etnik Türk azınlıklar, Bosnalı Müslümanlar, Arnavutlar ve Makedonlar) Osmanlı Devletinden kaynaklanan ortak tarihi bağa sahip olmasıdır. Nitekim bu çıkarlara dayanarak dönemin başbakanı Süleyman Demirel, "Balkanlar'da istikrar, barış ve işbirliğinin Türkiye için hayati öneme sahip olduğunu” belirtmiştir. Türkiye tarafından Yugoslavya'nın çözülmeye 
başlaması, Balkan devletlerinin Yunanistan-Sırp hegemonyası altına girmesi, bu doğrultuda da Türkiye'nin bölge halkları ile ilişkinin koparılması ve Batı Avrupa ile ilişkilere engel olması şeklinde algılanmıştır. Bu yüzden Türkiye, başlangıçta Yugoslavya'nın toprak bütünlüğünü savunmuş ardından Bosna-Hersek’te savaşın başlamasıyla birlikte bu politikasını değiştirmiş ve temel politikasını bu savaşı sonlandırmak, başka bölgelere sıçramasını önlemek şeklinde oluşturmuştur (Bazoğlu Sezer, 1996:99-102). Güvenlik dışında Türkiye'nin bu politikayı benimsemesini ve Bosna-Hersek Savaşında aktif rol üstlenmesi konstrüktivist teori açıklamaya geçmeden önce bu teorinin temel iddialarını hatırlamakta fayda vardır. Bunlar:

- $\quad$ Uluslararası siyaset teorisi için devletler analizin baş aktörleridir.

- $\quad$ Devletler sisteminde en önemli yapılar maddi değil intersübjektiftir.

- Devlet kimlikleri ve çıkarları sosyal yapılar tarafından inşa edilmiştir, bunlar sadece insan doğasına bağlı değildir (Wendt, 1994:385).

Genel olarak bu maddelere bağlı kalarak Türkiye'nin Bosna-Hersek Savaşında yürüttüğü politika konstrüktivist terori ile açıklanabilir. Bu doğrultuda Bosna'da savaşın çıktığı zamanlarda Türkiye'de, "Devlet" dış politika yapımı etkileyen ana aktör olduğu ifade edilebilir. Bu faktörle Türkiye dış politikada, kapasitesini gücüne uygun olarak kullanabilmiştir ancak bu faktör dış politikada tek belirleyici değildir. Kimlikler ve öznelerarası faktörlerde dış politika yapım sürecini belirleyen etkenler olmuşlardır. Bununla bağlantılı olarak konstrüktivizm, uluslararası yapının yalnızca maddi faktörler içermediği, maddi dünyalara anlam veren materyal yapılar tarafından inşa edildiği öncülüne dayanmaktadır. Bu bağlamda Türkiye'nin Bosna-Hersek Savaşında aktif rol oynamasının bir nedeni yüzyıllar içinde oluşturulan, Balkan mirasına ve kültürel kimliğine dayanmaktadır. Türkiye’nin uluslararası örgütler nezdinde çok taraflı müdahaleyi istemesinin en önemli nedenlerinden bir tanesi ortak tarihi mirastır (Ekinci, 2009:53).

Neo-realizmin aksine devlet kimliklerinin ve dış politikanın zaman içinde inşa edildiğini savunan konstrüktivizmin bu özelliği Türkiye'nin savaşta aktif rol üstlenmesinin bir diğer nedenini açıklamaktadır. Bu neden, 1923'te Cumhuriyetin ilan edilmesinden bu zamana Türk diş politikasının "Batı" yönelimli olduğudur. Bu politika zaman zaman meclisteki dini ve milliyetçi partiler tarafından eleştirilse de Türkiye, süreç içerisinde bu politikasından sapmamıştır. $\mathrm{Bu}$ duruma savaşın ilk aşamalarında Türkiye'nin Yugoslavya'nın toprak bütünlüğünü savunması örnek verilebilir. Benzer şekilde Batı, Yugoslavya'dan kopan Cumhuriyetleri tanıdığında Ankara'da bunu yapmıştır. Bu dönemde ortak tarihi mirastan dolayı Boşnaklara daha yakın duran Türkiye, İslami ülkeleri de harekete 
geçirmeye çalışsa da genel olarak Batı nezdindeki devletleri ve uluslararası örgütleri savaşa müdahil olması için daha çok çaba sarf etmiştir (Ekinci, 2009:54).

Ayrıca bu dönemde Türk dış politikasına o zamana kadar hâkim olan statüko geleneğinin aksine, Turgut Özal tarafından geliştirilen aktif dış politika dönemine geçildiği de hatırlanmalıdır. Soğuk Savaşın sonlanmasının ardından Türkiye'nin uluslararası arenada konumunun ne olacağı konusunda başlayan tartışmalara bu politika ile cevap verildiği söylenebilir. Bu doğrultuda Türkiye, Balkanlar, Kafkasya, Orta Asya ve Orta Doğu'da daha aktif bir dış politika izlemeye başlamıştır (Ekinci, 2009:55). Bu politikanın oluşumunda ve geliştirilmesinde merkezi rolü bulunan Özal, Türkiye’nin bölgesel rolünü arttırarak Batı'nın önemli bir müttefiki olmaya devam edeceği mesajını vermiştir. Turgut Özal ve sonrasında gelen Süleyman Demirel'in Bosna-Hersek savaşında gösterdiği aktif çabalar bunu açıkça göstermiştir. Buna örnek olarak o dönemde Tansu Çiller'in Benazir Butto ile birlikte Saraybosna'ya gidip savaşa uluslararası medyada dikkat çekmeye çalışmasını ve Demirel'in Franco Tudjman ile dostane ilişkiler kurarak arabuluculuk rolü üstlenmesi verilebilir (Çoşkun, 2007:55-60).

Son olarak konstrüktivizmin önemli konularından olan amillerin, kurumların sorumluluklarının dış politikayı etkilediği, konstrüktivist teori ile Bosna-Hersek Savaşı politikasını açıklayabilir. O dönemde genel olarak bütün siyasi partiler savaşı kendi pencerelerinden farklı değerlendirse de savaşın insani boyutu ve ortak tarihi miras paydasında buluşmuştur. Örneğin o dönemde koalisyon hükümeti olan DYP-SHP ortak sorumluluk alarak UNPROFOR'a asker gönderebileceğini açıklamıştır. Genelde bu koalisyon hükümeti özellikle de DYP dini çatışma söyleminden kaçınıp Bosna'daki savaşı katliam olarak nitelendirerek insani boyutuna dikkat çekmeye çalışmıştır. Yani Türkiye'yi Bosna' da dengeli ve temkinli bir dış politika izlemeye iten şey dini kimliğin değil insani bir sorumluluğun olmasıdır. Bununla birlikte sol partinin lideri olan Bülent Ecevit, hükümeti iyi tanımlanmış bir Balkan politikasına sahip olmamakla suçlarken, savaşın Müslümanlara karşı bir Haçlı Seferine dönüştüğünü belirterek insani sorumluluğu vurgulamıştır. Ayrıca bu dönemde daha belirgin dinsel motivasyonlara sahip olan Refah Partisi, savaşın başlı başına bir din savaşı olduğunu vurgulayarak daha müdahaleden yana tutum benimsemiştir. Ancak genelde bütün siyasi partiler sorumluluk alarak ve ortak tarihi mirasa vurgu yaparak savaşın sonlandırılması, barışçıl bir çözüm getirilmesi için aktif dış politikayı desteklemiştir (Ekinci, 2009:55-56).

Toparlanacak olunursa, Soğuk Savaştan sonraki dönemde Türk dış politikasında; "Batılı" kimliğin, Neo-Osmanlıcılık ve İslamcılığın etkili olduğu ifade edilebilir. Türkiye’nin Bosna-Hersek Savaşına yönelik politikasında ise "Batılı" kimlik ön plana çıkmıştır. Yukarıda da değinildiği üzere, Soğuk Savaşın ardından uluslararası konjonktür değişmiş ve bu yeni konjonktürde Türkiye, Batı dünyasına 
önemini hatırlatmak, uluslararası siyasette konumunu pekiştirmek istemiştir. Bu sebeple, Soğuk Savaş sonrası dönemde geleneksel "Batılı” kimlik sürdürülmeye çalışılmış ve Türkiye, Bosna-Hersek Savaşında aktif rol üstlenerek uluslararası platformda Batı dünyasına önemini kanıtlamaya çalışmıştır (Çoşkun, 2013:168 ve 2019:67). Ek olarak bu savaşta "Neo-Osmanlıcılık" ve "İslamcılık" kimliklerinin etkili olmamasının sebebi uluslararası ortamda Türkiye hakkında yanlış bir algının oluşmasının istenmemesidir. Çünkü oluşacak böyle bir algı yalnızca Türkiye'nin Batılı imajını zedelemekle kalmaz aynı zamanda Rusya, Yunanistan, Bulgaristan gibi ülkelerle de ilişkisine zarar verebilirdi (Çalış, 2001:137).

\section{SONUÇ}

Uluslararası ilişkilerin en temel konularını farklı bakış açılarıyla açıklayan konstrüktivizm gerçekliğin ve fikirlerin sosyal inşasını ele alan disiplinler arası bir yaklaşımdır. Maddi unsurları da önemseyen konstrüktivizm sosyal dünyanın oluşumunda düşüncel unsurların kurucu bir rolü olduğunu savunur. Konstrüktivizmde, sosyal alanlarda yaşanan yapısal değişimler ve bu değişimlerin tarihsel bağlam içerisinde nasıl oluştuğu çalışmalarının odak noktasıdır.

Konstrüktivistler, genel olarak sorgulanmadan kabul edilen gerçeklikle değil insanların ortaya çıkardığı gerçeklikle ilgilenir. İnsanlar dolayısıyla devletler, sistemi oluşturan faktörleri sistemle karş11ıklı etkileşim sürecinde inşa etmektedir. Bu doğrultuda, konstrüktivizmin de bireylerin ve devletlerin dahil olduğu sosyal etkileşim sürecini inceleyerek bir anlamda uluslararası toplumun sosyolojisini yaptığı ifade edilebilir.

Konstrüktivizmin en çok altını çizdiği şey devletlerin sosyal bir varlık, uluslararası ilişkilerin ise sosyal bir alan olduğudur. Bu sebeple de kuralların, kurumların, normların ve düşüncel unsurların siyasi rolü üzerinde durmuşlardır. Konstrüktivizme göre öznelerarası etkileşim; kurallar, normlar, diller, kültür ve ideolojiler üzerinden şekillenmektedir. Bu etkileşimin sonucunda da kimlikler ortaya çıar. $\mathrm{Bu}$ yüzden konstrüktivistler kimlik kavramının önemini sürekli vurgulamışlardır.

Psikolojiden sosyolojiye, tarihten siyasete kadar pek çok disiplinde yer alan kimlik kavramı için ortak bir tanıma ulaşmak zordur. Yine de kimlik kavramının 'kimsiniz' ya da 'kimlerdensiniz' sorularına verilen cevaplara bağlı olarak tanımlanmasında uzlaşı sağlanmıştır. İnşa edilen bir kavram olan kimlik, farklılık ilişkisi yoluyla oluşturulur. Bu bağlamda kimliğin belirlenmesinde 'öteki’ önemli bir yere sahiptir. Öteki tanımlanmadan ya da öteki ile kendi kimliği arasındaki farkın ayırdına varılmadan kimliği tanımlamak mümkün değildir.

Konstrüktivistler, analizlerinde kimlik kavramına diğer uluslararası ilişkiler teorilerinden daha fazla yer vermiştir. Kimlik inşasının önemine vurgu yapan konstrüktivizm, sosyal ilişkilerin temelinde 
sosyal aktörlerin kimliklerinin olduğunu savunmaktadır. Konstrüktivizm, devletleri sosyal aktörler olarak kabul eder ve devletleri kimlik oluşturmaya ihtiyaç duyan yapılar olarak tanımlar. Bu doğrultuda, konstrüktivizmin en önemli argümanı devletlerin uluslararası arenadaki davranışlarını kimliklerinin belirlediğidir.

Konstrüktivizme göre devletler yalnızca hayatta kalmak için politika yapmaz. Tarihsel süreç içerisinde şekillenen çıkarlar ve kimlikler, devletlerin kimliklerini dolayısıyla da çıkarlarını belirler. Devlet kimliklerinin ve çıkarlarının süreç içerisinde değişebileceğini ifade eden konstrüktivizm, devletlerin çıkarlarını kimlikleriyle içselleştirerek davrandıklarını vurgular. Bu durum Türkiye'nin Bosna-Hersek Savaşındaki politikasını açıklayabilir. Şöyle ki Türkiye'nin dış politikası Cumhuriyet'in ilanından itibaren Batı yönelimli olmuştur. Türkiye, savaşın başında Batı ile birlikte davranarak Yugoslavya'nın bütünlüğünden yana olduğunu ifade etmiş ardından Batı Yugoslavya'dan ayrılan Cumhuriyetleri tanıdığında Türkiye'de aynı şekilde davranmıştır. Ancak Türkiye savaşta Batı'dan farklı olarak Boşnakların tarafında olduğunu belirtmiştir. Devletler sisteminde en önemli yapıların maddi değil öznelerarası olduğunu belirten konstrüktivizm, Türkiye'nin bu davranışını açıklamaktadır. Boşnakların katledilmesine Batı'dan daha fazla tepki gösteren Türkiye'nin bu şekilde davranmasının nedeni; Boşnaklar ile Türkler arasında tarihsel süreç içerisinde oluşturulan, geliştirilen ve içselleştirilen kuvvetli bağ yani ortak tarihi mirastır. Bu miras ve ortak kültürel kimlik, Türkiye'nin uluslararası toplumda aktif rol üstlenerek savaşın bitirilmesinde çabalamasına neden olmuştur. 


\section{KAYNAKÇA}

Akdemir, E. (2009). 11 Eylül 2001, 11 Mart 2004 ve 7 Temmuz 2005 Terörist Saldırılarının Ardından İslam'ın Avrupa'da Algılanışı. Ankara Avrupa Çalışmaları Dergisi, 8(1), 1-26.

Alexandrov, M. (2003). The Concept State Identity in International Relations: A Theoretical Analysis. Journal of International Development and Cooperation, $10(1)$.

Aşkın, M. (2007). Kimlik ve Giydirilmiş Kimlikler. Atatürk Üniversitesi Sosyal Bilimler Enstitüsü Dergisi, 10(2),213-220.

Ateş, D. (2008). Uluslararası İlişkilerde Konstrüktivizm: Ortayol Yaklaşımının Epistemolojik Çerçevesi. Sosyal Bilimler Dergisi, 10(1),213-235.

Bağcı, H. (1994). Bosna-Hersek Soğuk Savaş Sonrası Anlaşmazlıklara Giriş. Ankara Üniversitesi Dil ve Tarih-Coğrafya Fakültesi Dergisi, 16.

Bazoğlu sezer, D. (1996). Turkish Security in the Shifting Balkans: Reorientation to a Regional Focus. K. Tsipis, içinde, Common Security Regimes in the Balkans, (s.95-138). New York: Columbia University Press.

Buzan, B., Waever, O. \& Wilde, J. (1998). Security A New Framework for Analysis. United States of America: Lynne Rienner Publishers.

Cekıc. S. (2018). Dayton Barış Antlaşmasının Meşrulaştırdığı Boşnak Soykırımı. İstanbul: Lutka Kitap Yayınc1lı.

Çalış, Ş. (2001). Turkey's Balkan Policy in the Early 1990s. Turkish Studies, 2(1), 135146.

Çoşkun, B. (2007). Ankara ve Berlin'in Bosna Savaşı'na Yönelik Politikaları: Karşılaştırmalı Bir İnceleme. Uluslararası İlişkiler, 4 (13), 57-88.

Çoşkun, B. (2011). Turkish Foreign Policy Toward The Bosnian War (1992-1995): A Constructivist Analysis. Karadeniz Araştırmaları, 28, 1-18.

Çoşkun, B. (2013). Turkey and Balkans: Overcoming Prejudices, Building Bridges and Constructing a Common Future. PERCEPTIONS: Journal of International Affairs, 18(2),163-184.

Çoşkun, B. (2019). Reconsidering Dilemmas of Turkey's Foreign Policy: The Case of the Balkans. Analysen Positionen Essays, 64-81.

Ekici, K.D. (2018). Sosyal Konstrüktivizme Göre Turgut Özal Dönemi Türk Dış Politikası (1983-1993). Doktora Tezi. Kocaeli: Kocaeli Üniversitesi.

Ekinci, D. (2009). The War in Bosnia-Herzegovina and Turkish Parliamentary Debates (1992-1995): A Constructivist Approach. Uluslararası İlişkiler, 6(20), 37-60. 
Emeklier, B. (2011). Uluslararası İlişkiler Disiplininde Epistomolojik Paradigma Tartışmaları: Post-pozitivist Kuramlar. Bilge Strateji,2(4), 143-192.

Emgili, F. (2012). Bosna-Hersek Trajedisinde (1992-1995) Türk Birliği. Güney-Doğu Avrupa Araştırmaları Dergisi, 21, 57-87.

Ereker, F. (2010). Dış Politika ve Kimlik: İnşacı Perspektiften Türk Dış Politikasının Analizi. Doktora Tezi. Ankara: Ankara Üniversitesi.

Ertem, H.S. (2012). Kimlik ve Güvenlik İlişkisine Konstrüktivist Bir Yaklaşım: Kimliğin Güvenliği ve Güvenliğin Kimliği. Güvenlik Stratejileri Dergisi, 8(16),177-237.

Fearon, J. (1999). What is Identity: As We Now Use The World. Draft Comments.

Fierke, K.M. (2013). Constructivism, T, Dunne, Kurki, M. \& Smith,S, içinde International Relations Theories Discipline and Diversity. United Kingdom:Oxford University Press.

Hogg, M. ve Terry, D. (2000). Social Identity and Sef-Categorization Process in Organizational Contexts. Academy of Management Review, 25(1), 121-140.

Hopf, T. (1998). The Promise of Constructivism in International Relations Theory. International Security, 23(1), 171-200.

Jackson, R. ve Sorensen, G. (2006). Introduction to International Relations Theories and Approaches. United Kingdom:Oxford University Press.

Kaçar, G. (2014). İnşacılık. 22 Ocak 2021 tarihinde http://www.tuicakademi.org/insacilik/ adresinden alindi.

Karabulut, B. (2015). Güvenlik: Küreselleşme Sürecinde Güvenliği Yeniden Düşünmek. Ankara: Barış Kitap.

Karabulut, B. (2016). Uluslararası İlişkiler: Kavramlar-Teoriler-Kurumlar. Ankara: Barış Kitap.

Karabulut, B. (2016). 15 Temmuz ve Türk Ulusal Kimliğin Uyanışı: Konstrüktivist Teori Perspektifinde Bir Analiz. Bilig, 79.

Karakoç, J. (2013). Konstrüktivizmde Dış Politika ve Etnik Kimlikler. Dokuz Eylül Üniversitesi İktisadi ve İdari Bilimler Fakültesi Dergisi, 28(2),131-160.

Karatay, O. (2002). Bosna-Hersek Barış Süreci. Ankara: KaraM.

Kaya, S. (2008). Uluslararası İlişkilerde Konstrüktivist Yaklaşımlar. Ankara Üniversitesi SBF Dergisi, 63(3).

Kenar, N. (2005). Bir Dönemin Perde Arkası Yugoslavya. Ankara: Palme Yayıncılık. 
Küçük, M. (2009). Uluslararası İlişkiler Kuramında Konstrüktivist Dönüşü Anlamak. Ege Akademik Bakış, 9(2),771-795.

Lazaro, J.B. (2019). European Identity and Its Importance To The EU. International Journal of Interdisciplinary Research in Arts and Humanities, 4(1), 87-89.

Oran, B. (1995). Türkiye'nin Balkan ve Kafkas Politikas1. Ankara Üniversitesi SBF Dergisi,50(1), 271-278.

Öner, A.Ş. (2013). Dram Sonrası Bosna. İstanbul: IQ Kültür Yayıncılık.

Övet, T. (2007). Avrupa Ötekisi. TASAM Stratejik Araştırmalar Dergisi. 11.

Özdemir, C. (2001). Kimlik ve Söylem. Osmangazi Üniversitesi Sosyal Bilimler Dergisi, $2,107-122$.

Özlem, K. (2012). Soğuk Savaş Sonrası Dönemde ABD’nin ve Türkiye'nin Balkanlar Politikalarının Bosna-Hersek, Kosova ve Makedonya Krizleri Örneğinde İncelenmesi. Trakya Üniversitesi Balkan Araştırma Enstitüsü Dergisi, 1(1),23-40.

Öztürk, E. (2014). Kimlik, Dış Politika ve Uzlaşma: İnşacı Kuram Çerçevesinde Ulusal Kimlikler ve İkili İlişkiler Üzerine Bir Değerlendirme. Yeni Türkiye. 60, 1-12.

Sabah (2010). Acı Rakamları ile Bosna Savaşı. Sabah Gazetesi, 7 Temmuz 2018 tarihinde https://www.sabah.com.tr/galeri/dunya/aci_rakamlari_ile_bosna_savasi/6 adresinden alındi.

Sağır, G. (2016). Türkiye'nin Bosna-Hersek Savaşındaki Politikası. 11 Kasım 2018 tarihinde http://www.uiportal.net/turkiyenin-bosna-hersek-savasindakipolitikasi.html adresinden alınd.

Sancaktar, C. (2010). Türkiye'nin Balkanlardan Kopuşu ve Geri Dönüşü. 23 Mart 2020 tarihinde https://tasam.org/trTR/Icerik/66/turkiyenin_balkanlardan_kopusu_ve_geri_donusu adresinden alındi.

Sindic, D. ve condor, S. (2014). Social Identity Theory and Self Categorization Theory. The Palgrave Handbook of Global Political Psychology, Basingstoke: Palgrave Macmillan.

Sonyel, S. R. (1994). The Muslims of Bosnia Genocide Of A People. United Kingdom: The Islamic Foundation.

Şimşek, S. (2002). Günümüz Kimlik Sorunu ve Bu Sorunun Yaşandığı Temel Çatışma Eksenleri. Uludağ Üniversitesi Fen-Edebiyat Fakültesi Sosyal Bilimler Dergisi,3(3), 29-39.

Tanrısever, O.F. (2019). Yöntem Sorunu: Gelenekselcilik Davranışsalcılık Tartışması, Dağı, İ.D., Eralp, A., Keyman, E.F., Polat, N., Tanrısever, O.F., Yalvaç, F., Yurdusev, A.N., içinde Devlet, Sistem ve Kimlik Uluslararası İlişkilerde Temel Yaklaşımlar, İstanbul: İletişim Yayıncılık (16.Baskı). 
Türbedar, E. (2008). Uluslararası Adalet Divanı'nda Görülen Dava Neden Önemliydi?. Elekdağ, S. ve Türbedar, E, içinde Uluslararası Suçlar: Bosna-Hersek Örneği. Ankara: Avrasya Stratejik Araştırmalar Merkezi, İnsanlığa Karşı Suçlar Araştırma Enstitüsü Yayınları.

Vukasovic, D. (2018). European Union and Otherness: The Case Of Balkans. Sprawy Narowosciowe Seria Nowa/Nationalities Affairs New Series.

Wendt, A. (1994). Collective Identity Formation and The International State. The American Political Science Review, 88(2).

Wendt,A. (1992). Anarchy Is What States Make Of It: The Social Construction Of Power Politics. International Organizations, 46(2),398.

Wendt, A. (2016). Uluslararası Siyasetin Sosyal Teorisi. H Ertem \& S. Öner (Çev.). İstanbul: Küre Yayınları. (Eserin orijinali 1999'da yayımlandı). 